\title{
The Src Homology 2 Domain Protein Shep1 Plays an Important Role in the Penetration of Olfactory Sensory Axons into the Forebrain
}

\author{
Lei Wang, ${ }^{1}$ Virginie Vervoort, ${ }^{1}$ Yann Wallez, ${ }^{1}$ Nathalie Coré, ${ }^{2}$ Harold Cremer, ${ }^{2}$ and Elena B. Pasquale ${ }^{1,3}$ \\ ${ }^{1}$ Sanford-Burnham Medical Research Institute, La Jolla, California 92037, ${ }^{2}$ Institut de Biologie du Développement de Marseille Luminy, Centre National de \\ la Recherche Scientifique/Université de Méditerranée, Campus de Luminy, 13288 Marseille, France, and 3Pathology Department, University of California, \\ San Diego, La Jolla, California 92093
}

\begin{abstract}
Shep1 is a multidomain signaling protein that forms a complex with Cas, a key scaffolding component of integrin signaling pathways, to promote the migration of non-neuronal cells. However, the physiological function of Shep1 in the nervous system remains unknown. Interestingly, we found that Shep1 and Cas are both concentrated in the axons of developing olfactory sensory neurons (OSNs). These neurons extend their axons from the olfactory epithelium to the olfactory bulb located at the anterior tip of the forebrain. However, in developing Shep1 knock-out mice, we did not detect penetration of OSN axons across the pial basement membrane surrounding the olfactory bulb, suggesting that Shep1 function is important for the establishment of OSN connections with the olfactory bulb. Interestingly, we observed reduced levels of Cas tyrosine phosphorylation in OSN axons of Shep1 knock-out mice, suggesting compromised Cas signaling function. Indeed, when embedded in a three-dimensional gel of basement membrane proteins, explants from Shep 1 knock-out olfactory epithelium extend neuronal processes less efficiently than explants from control epithelium. Furthermore, ectopic expression of Shep1 in non-neuronal cells promotes cell migration through a collagen gel. Later in development, loss of Shep 1 function also causes a marked reduction in olfactory bulb size and disruption of bulb lamination, which may be primarily attributable to the defective innervation. The greatly reduced OSN connections and hypoplasia of the olfactory bulb, likely resulting in anosmia, are reminiscent of the symptoms of Kallmann syndrome, a human developmental disease that can be caused by mutations in a growing number of genes.
\end{abstract}

\section{Introduction}

During early development of the olfactory system, developing olfactory sensory neurons (OSNs) in the nasal epithelium extend axons to the developing olfactory bulb at the anterior end of the forebrain (Key, 1998; St John et al., 2002; Nedelec et al., 2005; Mombaerts, 2006; Cho et al., 2009). An initially coarse projection map of OSNs to the olfactory bulb is later refined so that axons expressing the same odorant receptor project to defined glomeruli. Recent studies have identified a number of gene products that regulate establishment of the connectivity of OSN axons with the primordial olfactory bulb. These include fibroblast growth factor

Received June 25, 2010; revised July 30, 2010; accepted Aug. 3, 2010.

This work was supported by National Institutes of Health Grants CA102583 and HD025938 (E.B.P.), grants from the Agence Nationale de la Recherche and the Fondation pour la Recherche Médicale (H.C.), and a postdoctoral fellowship from the Fondation pour la Recherche Médicale (Y.W.). We thank A. Desoeuvre for performing some of the in situ hybridization experiments and F. Valencia for excellent technical assistance.

L.W. designed, performed, and interpreted all experiments, except for those shown in supplemental Figure 4, and co-wrote the manuscript. V.V. helped with the generation and characterization of the Shep1 knock-out mice. Y.W. helped with the assessment of milk uptake in newborn mice and with immunolabeling with the phosphospecific antibodies. N.C. performed in situ hybridization experiments shown in supplemental Figure 4. H.C. contributed to the design and interpretation of the experiments. E.B.P. designed and interpreted experiments and co-wrote the manuscript.

Correspondence should be addressed to Elena B. Pasquale, Sanford-Burnham Medical Research Institute, 10901 North Torrey Pines Road, La Jolla, CA 92037. E-mail: elenap@burnham.org.

DOI:10.1523/JNEUROSCI.3289-10.2010

Copyright $\odot 2010$ the authors $\quad 0270-6474 / 10 / 3013201-10 \$ 15.00 / 0$
8 (FGF8) (Chung et al., 2008), the secreted protein prokineticin-2 and its receptor prokineticin receptor-2 (Matsumoto et al., 2006; Pitteloud et al., 2007), Wnt ligands and their receptor Frizzled7 (Zaghetto et al., 2007), the secreted morphogen Sonic hedgehog homolog (Balmer and LaMantia, 2004), and several transcriptional regulators that control complex programs of gene expression (Yoshida et al., 1997; Levi et al., 2003; Long et al., 2003; Balmer and LaMantia, 2004; Laub et al., 2005; Yoshihara et al., 2005; Hirata et al., 2006; Watanabe et al., 2009). However, little is known about the intracellular signaling molecules regulating OSN connectivity.

Shep1 (also known as Sh2d3c, Nsp3, and Chat) is a member of a family of three cytoplasmic signaling proteins characterized by a unique domain structure that comprises an Src homology 2 (SH2) domain for association with tyrosine phosphorylated proteins, a proline/serine-rich region, and a guanine-nucleotide exchange factor-like (GEF-like) domain (Dodelet et al., 1999; Vervoort et al., 2007). The GEF-like domain of Shep1 not only binds Ras family proteins that regulate integrin activity but also has the unusual ability to constitutively associate with the scaffolding proteins of the Cas family, which function downstream of integrins (Tikhmyanova et al., 2010). Shep 1 also contains an $\mathrm{N}$-terminal region that varies in different Shep 1 isoforms and a C-terminal PDZ (postsynaptic density-95/Discs large/zona 
occludens-1) domain-binding motif that is not present in the other family members.

The Shep1 family plays an important role in cell-substrate adhesion and migration/invasion. For example, Shep1 promotes adhesion and migration of T-cells and other cell types (Sakakibara et al., 2002; Dail et al., 2004; Regelmann et al., 2006), and BCAR3/AND-34 promotes breast cancer cell migration and invasiveness (Schrecengost et al., 2007). NSP1, the least characterized family member, has a more limited distribution in human tissues and is not expressed in the mouse ( $\mathrm{Lu}$ et al., 1999; Vervoort et al., 2007).

Shep1 is most highly expressed in the brain, vasculature, and immune cells (Sakakibara and Hattori, 2000; Vervoort et al., 2007). However, its in vivo function is poorly understood. To gain insight into the physiological role of Shep1, we inactivated the Shep 1 gene in the mouse. This revealed that Shep1 plays an important role in the early ingrowth of peripheral OSN axons into the forebrain. In developing Shep 1 knock-out mice, OSN axons are detected only outside the forebrain, indicating that their connections with the olfactory bulb are severely disrupted, and the olfactory bulb does not develop properly.

\section{Materials and Methods}

Plasmids. The pcDNA3-Shep1 plasmid, encoding the mouse Shep $1 \beta$ isoform (Vervoort et al., 2007), has been described previously (Dail et al., 2004). The pcDNA3-Shep $1 \Delta \mathrm{N}$ plasmid encodes a truncated form of Shep1 that comprises amino acids 240-702 and lacks the $\mathrm{N}$ terminus, the $\mathrm{SH} 2$ domain, and part of the proline/serine-rich region and mimics a form of Shep1 expressed in the Shep1 knockout mice (Roselli et al., 2010).

Primary antibodies. The anti-Shep1 rabbit polyclonal antibody used for immunohistochemistry (Shep1-SH2 antibody) was generated by immunizing rabbits with a glutathione $S$-transferase (GST) fusion protein of amino acids $1-172$ of the mouse $\beta$ isoform, affinitypurified on a column containing the antigen, and absorbed on a column containing a GST fusion protein of the $\mathrm{SH} 2$ domain of $\mathrm{ShcB}$, which is closely related to that of SHEP1, to remove antibodies that may recognize epitopes conserved in different SH2 domains (Dodelet et al., 1999). An antibody was also generated in chicken using the same antigen, purified from egg yolks, and used for immunoblotting. Another rabbit polyclonal antibody (Shep1-GEF antibody) was generated using a GST fusion protein of the GEF-like domain (amino acids 362-702 of the $\beta$ isoform), affinity-purified on a column containing the antigen, and absorbed on a GST column. Finally, a rabbit polyclonal antibody was generated using as the antigen a peptide comprising the $11 \mathrm{C}$-terminal residues (692-702; Shep1-C-term antibody) coupled to BSA with glutaraldehyde. The immune serum was
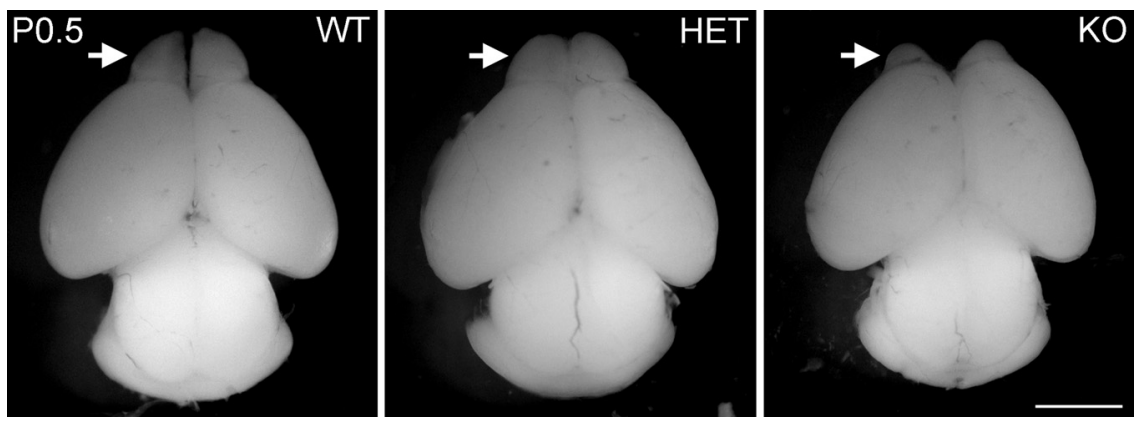

Figure 1. Shep 1 knock-out mice have small olfactory bulbs. Photographs from above of dissected brains from P0.5 Shep1 wild-type (WT), heterozygous (HET), and knock-out (KO) mice. Arrows point to the olfactory bulbs. Scale bar, $2 \mathrm{~mm}$.
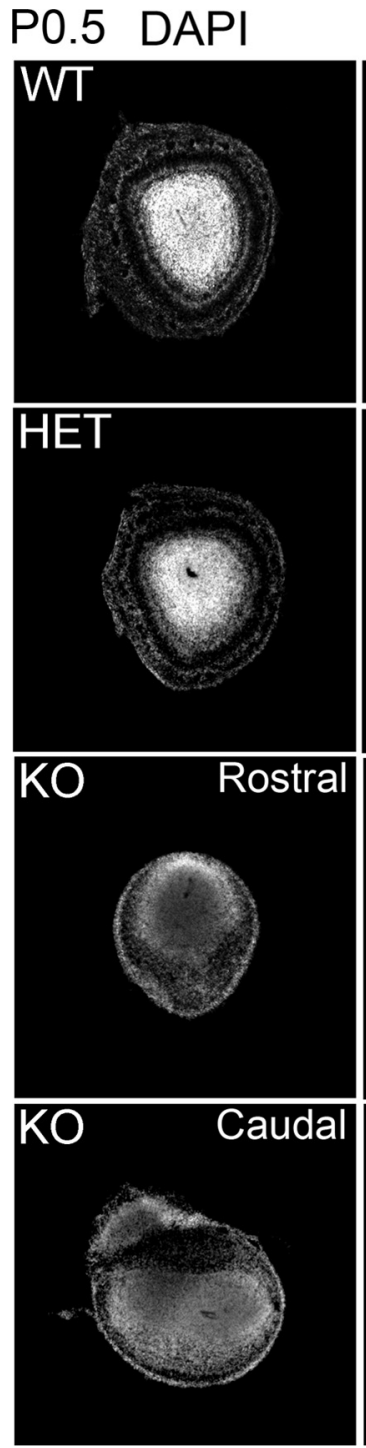

Figure 2. Defective presynaptic innervation in Shep1 knock-out olfactory bulbs at P0.5. Coronal sections of olfactory bulbs from P0.5 Shep1 wild-type (WT), heterozygous (HET), and knock-out (KO) mice were labeled with DAPI and antibodies recognizing the axonal protein olfactory marker protein (OMP) and the presynaptic protein syntaxin-1. Scale bar, $250 \mu \mathrm{m}$.
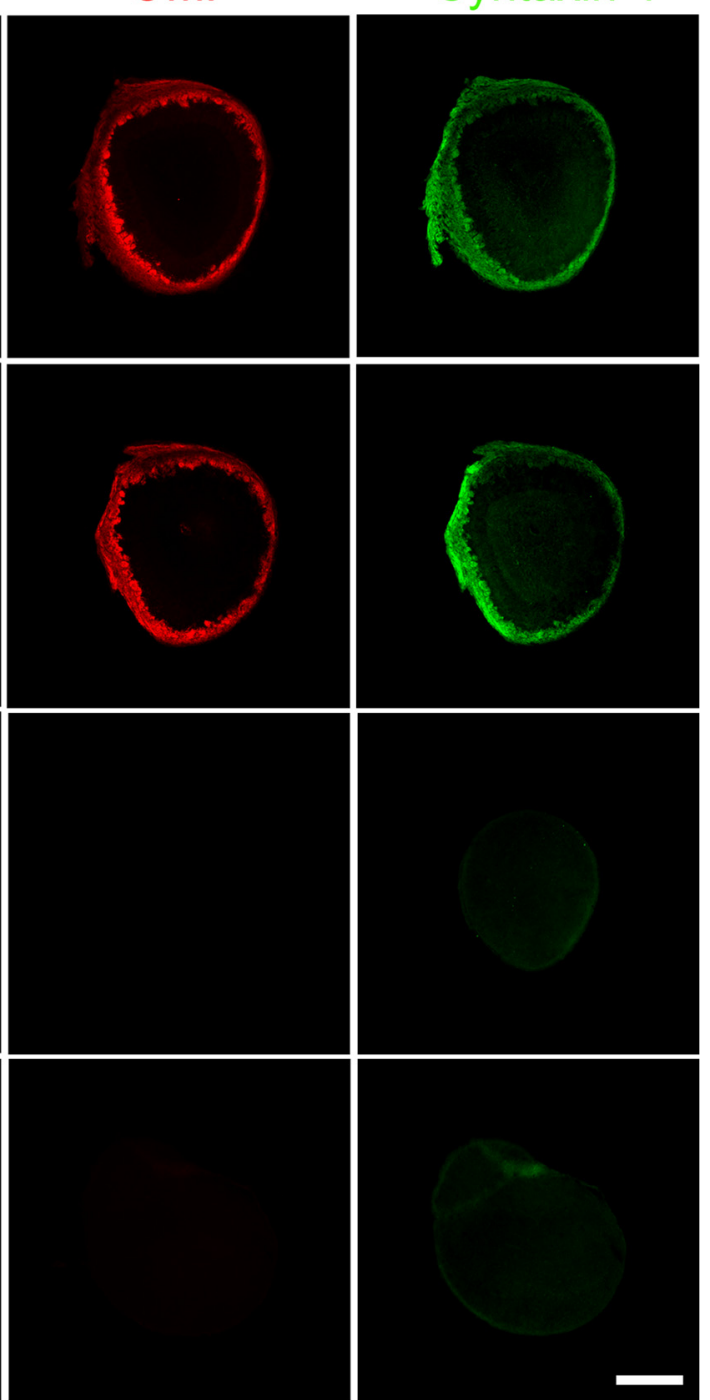

affinity purified on a column obtained by coupling the peptide to AffiGel 10 (Bio-Rad) or on a GST-GEF column. The Shep1-SH2 and C-terminal antibodies were used for immunoprecipitations $(10 \mu \mathrm{g})$ and immunoblotting $(2 \mu \mathrm{g} / \mathrm{ml})$. The following primary antibodies were also used for immunoblotting: insulin-like growth factor-1 (IGF-1) receptor $\beta$ (1:1000; Cell Signaling Technology) and anti-phosphotyrosine (4G10, 
A
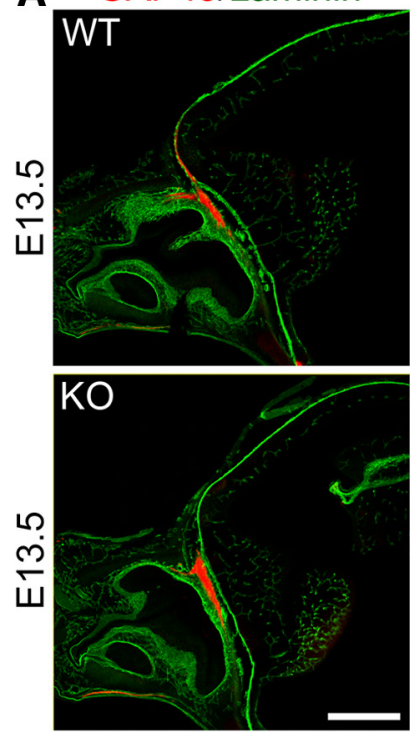

B
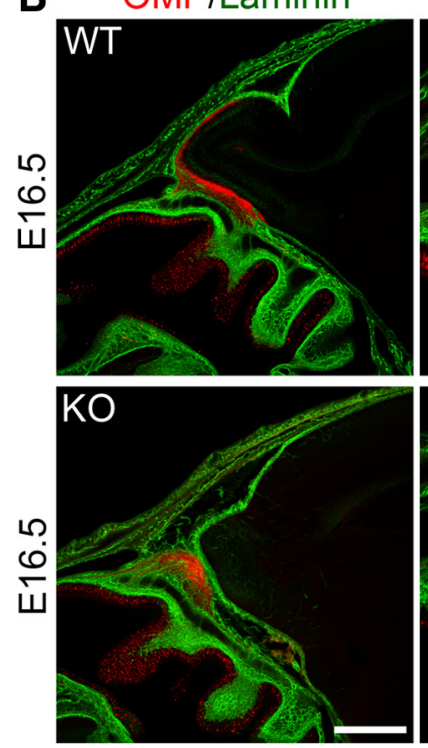

GAP43/Laminin
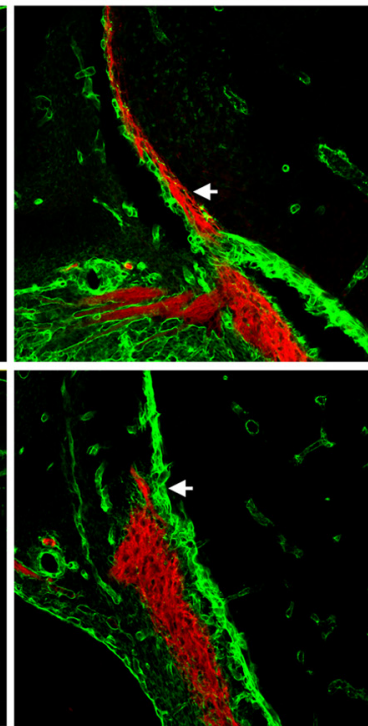

OMP/Laminin
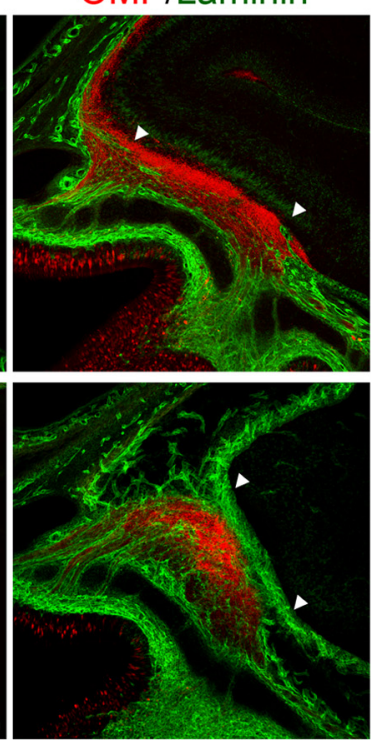

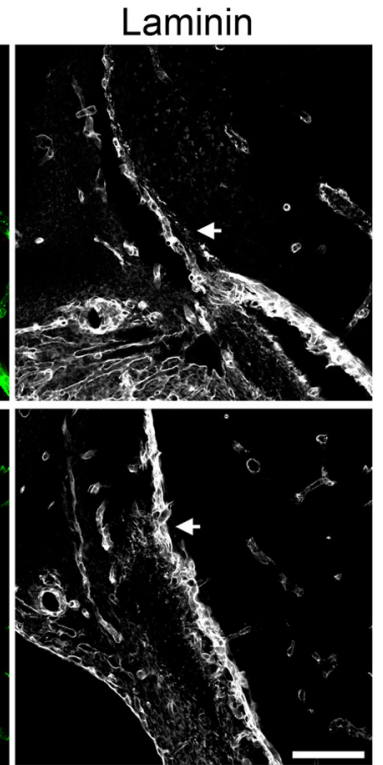

Laminin
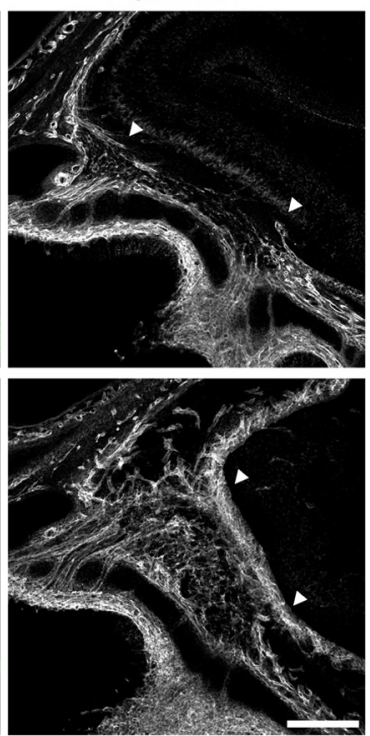

Figure 3. OSN axons stall outside the pial basement membrane at E13.5 and E16.5. A, Sagittal sections of wild-type (WT) and Shep1 knock-out (KO) E13.5 embryos. OSN axons were labeled with an anti-GAP43 antibody, and the pial basement membrane was visualized with an anti-laminin antibody. Arrows mark OSN axons, which cross the basement membrane in wild-type mice but appear to remain outside the brain in the Shep 1 knock-out mice. Scale bars: for the left panels, $500 \mu \mathrm{m}$; for the middle and right panels, $100 \mu \mathrm{m}$. B, Sagittal sections of wild-type (WT) and Shep 1 knock-out (K0) E16.5 embryos. The OSN axons were labeled with an anti-olfactory marker protein (OMP) antibody, and the basement membrane was visualized with an anti-laminin antibody. Arrowheads mark axons that have crossed the basement membrane in the WT, whereas axons appear to remain outside the brain in the Shep1 knock-out mice. By E16.5, the basement membrane is highly fenestrated in wild-type embryos but appears continuous in the Shep1 knock-out mice. Scale bars: for the left panels, $100 \mu \mathrm{m}$; for the middle and right panels, $50 \mu \mathrm{m}$.

1:1000; Millipore Corporation). The following primary antibodies were used for immunohistochemistry: collagen I (1:200 dilution of 1.17 $\mathrm{mg} / \mathrm{ml}$ stock; Rockland), cleaved caspase-3 (1:100; Cell Signaling Technology), growth-associated protein 43 (GAP43) (1:50 dilution of 0.5 $\mathrm{mg} / \mathrm{ml}$ stock; Invitrogen), gonadotropin-releasing hormone (GnRH) (1: 5000; Millipore Corporation), laminin (1:200; Sigma), olfactory marker protein (1:5000; Wako Fine Chemicals), rabbit Shep1-SH2 $(10 \mu \mathrm{g} / \mathrm{ml})$, synptophysin-1 (1:100; Sigma), syntaxin-1 (1:200; Sigma), $\beta$ III-tubulin (TuJ1 antibody; 1:5000 dilution of $1 \mathrm{mg} / \mathrm{ml}$ stock; Covance Research Products), polysialic acid-neural cell adhesion molecule (1:500; Millipore Corporation), Cas (1:100; Santa Cruz Biotechnology), phosphoCas Y410 (1:100; Cell Signaling Technology), phosphoSrc Y418 (1:100; Invitrogen), $S 100 \beta$ (1:100; AbCam), and p75NTR neurotrophin receptor
(1:50; Santa Cruz Biotechnology). Concentrations of commercial antibody stocks are indicated when available.

Shep1 knock-out mice. The Shep1 knock-out mice were commissioned to the company Ozgene. A C57BL/6 mouse line was generated with loxP sites for Cre recombinase flanking exon 7 of Shep1, which encodes most of the SH2 domain (Vervoort et al., 2007; Roselli et al., 2010). The Shep $1^{\text {flox }}$ mice were crossed with mice expressing Cre recombinase in the germ line to generate a Shep 1 knock-out line in which all known mouse isoforms (Vervoort et al., 2007) are inactivated by Cre-mediated deletion of the floxed exon encoding the $\mathrm{SH} 2$ domain.

Immunohistochemistry. Embryonic day 12.5 (E12.5) to postnatal day 0.5 (P0.5) mouse brains were fixed in $4 \%$ formaldehyde in PBS for 1 week at $4^{\circ} \mathrm{C}$; adult mice were perfused transcardially with $4 \%$ formaldehyde in PBS, and brains were further incubated in fixative overnight at $4^{\circ} \mathrm{C}$. Fixed tissues were equilibrated in $30 \%$ sucrose in PBS, embedded in OCT compound (Tissue-Tek; Sakura), and allowed to freeze slowly in a slurry of dry ice and dimethylbutane. Twenty to $40 \mu \mathrm{m}$ cryostat sections were washed three times in PBS and blocked with 5-10\% serum in PBS, 0.1-0.25\% Triton X-100 for $10 \mathrm{~min}$ to $1 \mathrm{~h}$ at room temperature. Primary antibodies were added to the blocking solution and incubated at $4^{\circ} \mathrm{C}$ with gentle agitation for $16-48 \mathrm{~h}$. The sections were washed in PBST (PBS, 0.15\% Triton X-100) three times, 15 min each, with gentle agitation. Alexa fluorochrome-conjugated secondary antibodies (Invitrogen) were diluted at 1:200 in blocking solution and incubated with the sections for $1-2 \mathrm{~h}$ at room temperature. Tissues sections were counterstained with $4^{\prime}, 6^{\prime}$ diamidino-2-phenylindole (DAPI) (1:5000; Sigma) or NeuroTrace (1:200; Invitrogen) and mounted in Vectashield mounting medium (Vector Laboratories). P0.5 brains were similarly processed for paraffin sections $(8 \mu \mathrm{m})$, which were stained with cresyl violet (Nissl stain). For Shep1 immunohistochemistry, the embryos were incubated in $4 \%$ formaldehyde for $2 \mathrm{~h}$ at room temperature. Cryosections $8 \mu \mathrm{m}$ in thickness were adhered to Snowcoat X-tra microslides (Surgipath). The Shep1-SH2 antibody $(10 \mu \mathrm{g} / \mathrm{ml})$ was preaborbed on cryosectioned embryonic knock-out tissue slices before applying on the sections. In experiments in which sections were immunolabeled with phosphoCas- or phosphoSrc-specific antibodies, $1 \mathrm{~mm}$ of the protein tyrosine phosphatase inhibitor sodium orthovanadate was included in all the solutions.

In situ hybridization. An antisense RNA probe corresponding to nucleotides 2525-2846 of Shep1 (GenBank accession number AF168364) was generated using the Dig-RNA labeling kit (Roche). Tissue preparation and in situ hybridization have been described in detail previously (Tiveron et al., 1996; Zimmer et al., 2004).

Olfactory neuroepithelium explant cultures. E14.5 olfactory neuroepithelium was dissected, cut into small pieces, and kept in ice-cold Neurobasal medium (Invitrogen) for $30 \mathrm{~min}$ to $1 \mathrm{~h}$. For two-dimensional growth, explants were plated for $4 \mathrm{~h}$ onto glass coverslips precoated with $10 \mu \mathrm{g} / \mathrm{ml}$ poly-D-lysine (Sigma), $10 \mu \mathrm{g} / \mathrm{ml}$ laminin (BD Biosciences), and 5-10\% GelTrex (Invitrogen), which is a low-growth-factor-containing, defined-component mixture of extracellular matrix proteins. For three- 

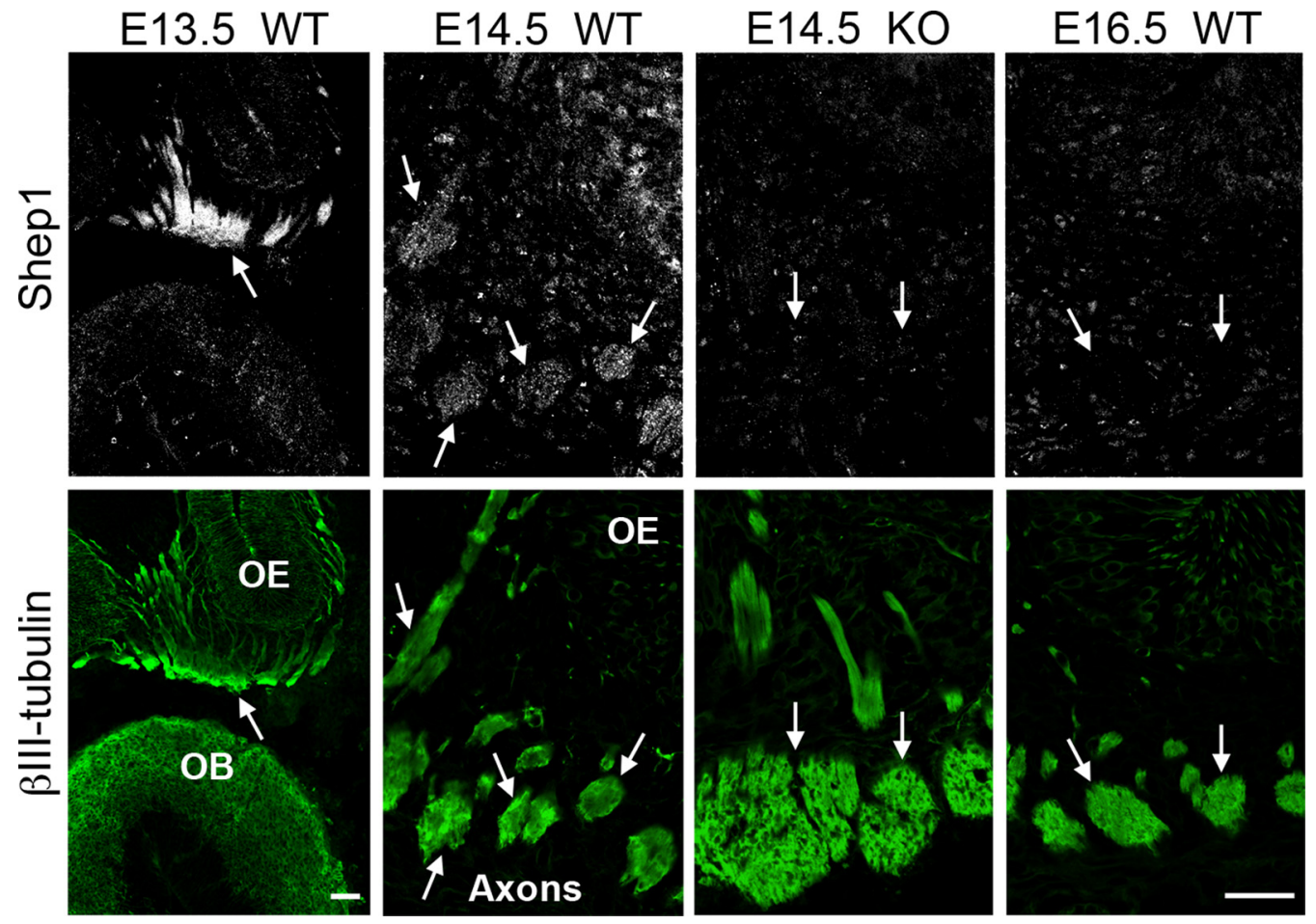

Figure 4. Shep1 is expressed in OSN axons at E13.5-E14.5. Coronal sections of olfactory epithelium (OE) at E13.5, E14.5, and E16.5 were labeled for Shep1. The sections were double labeled for $\beta$ III-tubulin to visualize OSN axons. Shep1 was detected in axons from wild-type E13.5 and E14.5 embryos but not Shep 1 knock-out E14.5 embryos. Shep1 immunoreactivity was greatly reduced in wild-type E16.5 axons. Arrows point to axon bundles. E14.5 and E16.5 sections were stained and photographed in parallel. Scale bars, $50 \mu \mathrm{m}$.

dimensional growth, explants were subsequently embedded in $50 \%$ GelTrex (Invitrogen), which was allowed to gel for $\sim 1 \mathrm{~h}$ at $37^{\circ} \mathrm{C}$ in a standard cell culture incubator. Neurobasal medium supplemented with 2\% B27 supplement (Invitrogen), 0.5 mM L-glutamine, 0.25\% penicillin/ streptomycin, and $20 \mathrm{~nm}$ IGF-1 (R \& D Systems) was then added. The explants were cultured for $5 \mathrm{~d}$ before fixation and immunostaining with TuJ1 antibody.

To quantify the halo of processes surrounding the explants, the immunofluorescence images of the TuJ1 antibody detecting $\beta$ III-tubulin were converted to binary images, and the area of bright pixels occupied by the axon halo (excluding the area occupied by the explanted tissue) was quantified in NIH ImageJ. The radius of the circular ring that contains $95 \%$ of the total bright pixels (not including the explanted tissue) was quantified. We also separately quantified the length of the three longest neurites in each explant (indicated as "maximal length" in Fig. $6 B, D$ ).

Cell culture and transfections. Human embryonic kidney HEK 293 cells were cultured in DMEM supplemented with 10\% fetal bovine serum and transfected with Superfect transfection reagent (Qiagen) or Lipofectamine2000 (Invitrogen) according to the recommendations of the manufacturer

Transwell invasion assays. Cell invasion through collagen I was measured using the QCM ECMatrix Cell Invasion Assay kit (Millipore Corporation). HEK 293 cells, $2 \times 10^{5}$, transfected with wild-type Shep1, Shep $1 \Delta \mathrm{N}$, or control vector were plated in the upper chamber in DMEM and $10 \%$ fetal bovine serum, and $50 \mathrm{~nm}$ IGF was added to the bottom chamber. Cells that had migrated to the bottom chamber were counted after $72 \mathrm{~h}$ in six $20 \times$ microscope fields in each of two to four wells for each construct in each of three independent experiments. Similar transfection efficiencies were obtained for the different constructs.

Immunoprecipitation and immunoblotting. Cultured cells were lysed in a buffer containing $20 \mathrm{~mm}$ Tris, $\mathrm{pH} 7.5,150 \mathrm{~mm} \mathrm{NaCl}, 0.5 \%$ Triton $\mathrm{X}-100,10 \mu \mathrm{g} / \mathrm{ml}$ aprotinin, $10 \mu \mathrm{g} / \mathrm{ml}$ leupeptin, $10 \mu \mathrm{g} / \mathrm{ml}$ pepstatin, 2 mM sodium orthovanadate, $10 \mathrm{~mm}$ sodium fluoride, and serine/threonine phosphatase inhibitor cocktail 1 (Sigma). The lysates were passed through a 21 gauge needle several times, followed by centrifugation at $15,000 \mathrm{rpm}$ for $15 \mathrm{~min}$. The supernatant was precleared with gamma beads for $30 \mathrm{~min}$ at $4^{\circ} \mathrm{C}$ and adjusted to a final concentration of $0.5-1$ $\mathrm{mg} / \mathrm{ml}$ total protein. Anti-Shep1-GEF antibody was incubated with Gamma beads (GE Healthcare) in lysis buffer containing 0.5\% BSA for $30 \mathrm{~min}$ at room temperature. After incubating with the lysates for $2 \mathrm{~h}$ at $4^{\circ} \mathrm{C}$, the beads were washed three to four times with lysis buffer, boiled in SDS-containing sample buffer for $10 \mathrm{~min}$, and separated by SDS-PAGE. For immunoblotting, polyvinylidene difluoride membranes (Millipore Corporation) were incubated overnight with primary antibodies at $4^{\circ} \mathrm{C}$, washed, and incubated with secondary horseradish peroxidaseconjugated antibodies for $1 \mathrm{~h}$ at room temperature.

\section{Results}

\section{Shep1 knock-out mice have small olfactory bulbs}

To investigate the physiological function of Shep1, we used Shep1 knock-out mice. Homozygous knock-out mice lack the Shep1 full-length protein, although in most tissues examined, they express a $\sim 55 \mathrm{kDa}$ C-terminal fragment that likely originates by alternative translation initiation from an internal AUG in the Shep 1 mRNA lacking the exon encoding most of the SH2 domain (Roselli et al., 2010). This fragment lacks the $\mathrm{N}$ terminus, the SH2 domain, and a portion of the proline/serine-rich region. Most Shep 1 knock-out mice die in the first day after birth, whereas the heterozygous mice are viable, fertile, and appear indistinguishable from their wild-type littermates. Examination of the overall appearance and cytoarchitecture of various organs at P0.5 did not reveal obvious abnormalities, except that the olfactory bulbs are markedly reduced in size (Fig. 1) (supplemental Fig. 1, available at www.jneurosci.org as supplemental material). The hypoplastic olfactory bulb phenotype is highly penetrant. In a cohort of 100 newborn pups examined, it was observed in 90\% (23 of 25) of the Shep1 knock-outs but none of their wild-type $(n=28)$ or heterozygous $(n=47)$ littermates. The olfactory bulb defect prompted us to examine the role of Shep1 in the development of the primary olfactory system. 


\section{Deficient innervation in the P0.5 olfactory bulb of Shep 1 knock-out mice}

While dissecting unfixed brains, we noticed that the olfactory bulbs of Shep1 knock-out mice detach readily from the cribriform plate, the bony boundary between the brain and the nasal cavity. At neonatal stages, the olfactory bulb should be firmly attached to the nasal cavity by the olfactory nerve, which extends from the olfactory epithelium through the openings in the cribriform plate into the olfactory bulb. Therefore, we suspected that primary OSN axons might not be connected to the olfactory bulb in the Shep1 knock-out mice.

To confirm this hypothesis, we performed immunolabeling experiments. At birth, OSN axons have entered the olfactory bulb and form the nerve fiber layer at its circumference. The axon terminals of OSNs make synaptic connections on the dendritic trees of secondary projection neurons (mitral cells and tufted cells), forming the axonal component of the glomerular layer ( $\mathrm{St}$ John et al., 2002; Nedelec et al., 2005; Mombaerts, 2006). We visualized OSN axons in coronal sections of P0.5 olfactory bulbs by immunolabeling for olfactory maker protein, a cytoplasmic protein selectively expressed in OSNs (Rogers et al., 1987; Nedelec et al., 2005). Olfactory marker protein immunoreactivity was evident in the nerve fiber layer and the glomerular layer of wildtype and heterozygous olfactory bulbs (Fig. 2). In contrast, no immunoreactivity was detected in the olfactory bulbs of Shep 1 knock-out mice, which also showed abnormal cellular organization of the outer layers in DAPI-stained sections. Immunolabeling with antibodies to the presynaptic proteins syntaxin-1 (Fig. 2) and synaptophysin 1 (data not shown) was similarly greatly reduced in the Shep1 knock-out mice, which confirms that Shep1 plays a crucial role in the innervation of the olfactory bulb by OSN axons.

OSN axons of Shep1 knock-out mice show severely impaired ability to reach the developing olfactory bulb

Next, we examined the primary olfactory system at earlier developmental stages. OSN axons start to extend at E11 toward the anterior portion of forebrain, in which the primordial olfactory bulbs form (Treloar et al., 1996; Key, 1998; St John et al., 2002). The axons transiently stall outside the basement membrane surrounding the brain before entering the ventromedial telencephalon at E12.5-E13.5. Because olfactory marker protein expression is not detectable at these early stages, we stained olfactory sensory axons with GAP43, a membrane protein expressed specifically in growing axons. We also labeled the basement membrane surrounding the telencephalon for laminin, which is an abundant component of embryonic basement membranes.

As shown in Figure 3A, in both wild-type and Shep1 knockout mice, the OSN axons grow and coalesce normally in the nasal mesenchyme. By E13.5, they have reached the boundary between the nasal mesenchyme and the forebrain. The wild-type axons pierce through the basement membrane and extend in the marginal zone of the forming olfactory bulb (Treloar et al., 1996), whereas the Shep1 knock-out axons appear to stall outside the basement membrane (Fig. $3 A$ ) and are still detected only outside the olfactory bulb at E16.5 (Fig. 3B). At this stage, the wild-type basement membrane contains extensive fenestrations filled with OSN axons (Treloar et al., 1996), whereas the basement membrane surrounding the Shep1 knock-out olfactory bulb still appears continuous (Fig. 3B). Severely impaired olfactory bulb innervation was observed throughout a series of sagittal sections encompassing the entire E16.5 olfactory bulb, excluding the possibility that the defects in OSN axon connectivity may involve
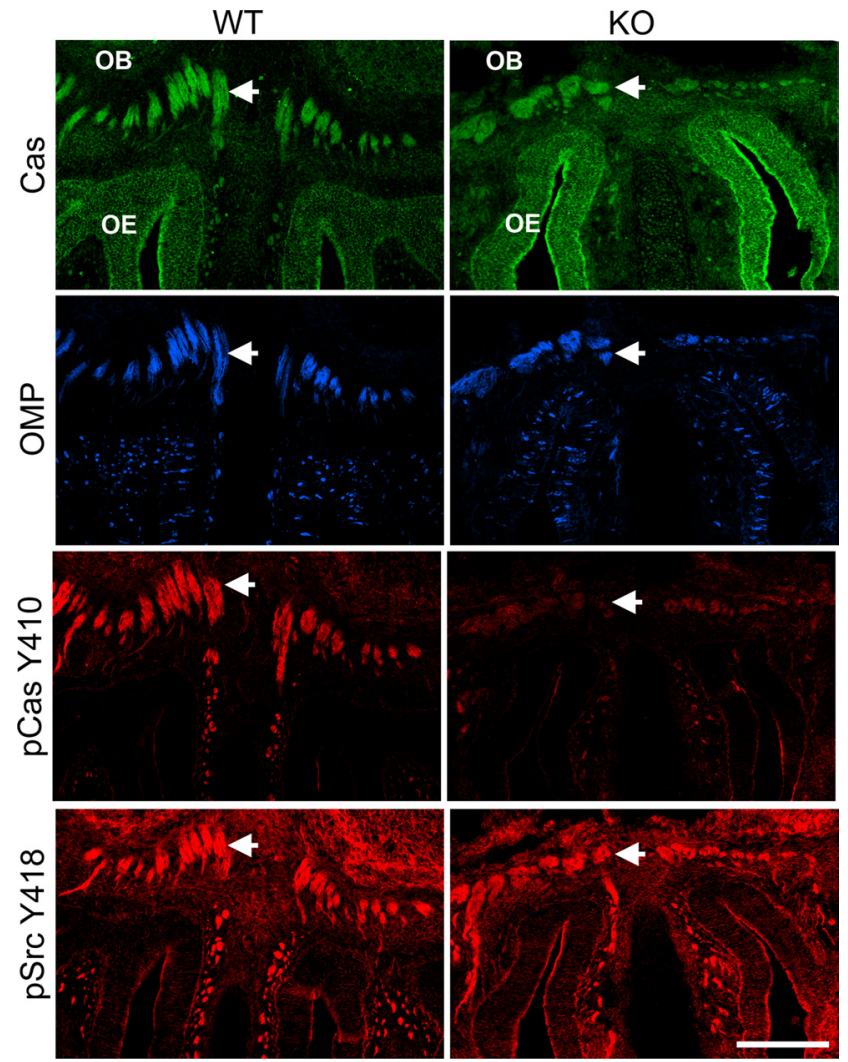

Figure 5. Tyrosine-phosphorylated Cas is concentrated in wild-type OSN axons and greatly reduced in Shep1 knock-out axons. Consecutive coronal sections (10 $\mu \mathrm{m}$ apart) from E14.5 wild-type and Shep1 knock-out mice were labeled for Cas together with olfactory marker protein (OMP), phosphoCas Y410, or phosphoSrc Y418. Tyrosine-phosphorylated Cas, total Cas, and activated Src kinases (detected with the phosphoSrc Y418 antibody, which recognizes a phosphorylated tyrosine in the activation loop of different Src family kinases) are concentrated in wild-type OSN axons but not the OSN cell bodies, which are located in the olfactory epithelium and labeled by the anti-olfactory marker protein antibody. The arrows point to the OSN axon fascicles on the left side. OB, Olfactory bulb; OE, olfactory epithelium. Scale bar, $200 \mu \mathrm{m}$.

only a portion of the olfactory bulb (supplemental Fig. 2, available at www.jneurosci.org as supplemental material). Furthermore, we did not detect an increase in the number of apoptotic cells in the olfactory epithelium or olfactory bulb of Shep 1 knockout mice at E13.5 or E14.5 (supplemental Fig. 3, available at www.jneurosci.org as supplemental material) (data not shown), indicating that the defective olfactory bulb innervation is not a secondary effect attributable to cell death. Together, these observations show that Shep1 function is important for the establishment of OSN axon connections with the olfactory bulb.

\section{Shep1 is concentrated in OSN axons}

In situ hybridization experiments revealed that Shep 1 mRNA is expressed in the olfactory epithelium at E13.5 (supplemental Fig. 4 , available at www.jneurosci.org as supplemental material). Expression is maintained at E15.5 and lower at P1. Although at E13.5 Shep1 mRNA is expressed over the entire olfactory epithelium, at later stages it appears concentrated in the OSNs but low or absent in the basal cells and the sustentacular cells lining the lumen. Furthermore, Shep 1 mRNA is expressed diffusely in the primordium of the olfactory bulb at E13.5 (supplemental Fig. $4 A$, available at www.jneurosci.org as supplemental material), although at later stages expression in the olfactory bulb is primarily detected in mitral cells (supplemental Fig. $4 B, C$, available at www.jneurosci.org as supplemental material). 
Double immunolabeling for Shep 1 and $\beta$ III-tubulin, which is a marker for developing axons, revealed high levels of Shep1 protein in the E13.5 and E14.5 wild-type OSN axons (Fig. 4). In contrast, Shep1 staining does not overlap with the staining for the ensheathing cell markers $\mathrm{S} 100 \beta$ at E12.5 (supplemental Fig. 5, available at www.jneurosci.org as supplemental material) and p75NTR neurotrophin receptor at E14.5 (supplemental Fig. 6, available at www.jneurosci.org as supplemental material). Furthermore, Shep 1 protein is barely detectable in the olfactory bulb and undetectable in the nasal mesenchyme. Shep1 immunoreactivity is also low in the olfactory epithelium, in which the cell bodies of OSNs are located. Together, these data suggest that, in the E13.5-E14.5 olfactory system, Shep1 is preferentially localized in OSN axons. By E16.5, when many of the OSN axons have already entered the olfactory bulb and the basal lamina is highly fenestrated, only low Shep 1 immunoreactivity was detectable (Fig. 4).

\section{Cas tyrosine phosphorylation is} drastically reduced in OSN axons from Shep 1 knock-out mice

Shep1 forms a signaling complex with Cas, a scaffolding protein that is highly expressed in axons and that has been implicated in axon growth and guidance by acting in concert with Src family kinases and integrins (Yang et al., 2002; J. Huang et al., 2006; Z. Huang et al., 2007; Liu et al., 2007). We detected high levels of Cas immunoreactivity in both wild-type and knock-out E14.5 OSN axons labeled with olfactory marker protein (Fig. 5). Remarkably, an antibody detecting tyrosine phosphorylation in the Cas substrate domain strongly labeled wild-type OSN axons at both E12.5 and E14.5, whereas phosphoCas immunoreactivity in the Shep1 knock-out axons was very low (Fig. 5) (supplemental Fig. 7, available at www.jneurosci.org as supplemental material). Src family kinases are responsible for Cas substrate domain phosphorylation, and indeed activated Src kinases (detected with an antibody to phosphorylated tyrosine 418 in the Src activation loop) are also concentrated in OSN axons of both wild-type and knock-out mice (Fig. 5). These results reveal that, in the absence of full-length Shep1, Cas tyrosine phosphorylation in OSN axons is low even in the presence of high levels of activated Src family kinases. Thus, Shep1 is required for efficient Cas tyrosine phosphorylation in OSN axons.

\section{Shep1 promotes OSN axons outgrowth through} extracellular matrix

Because Shep1 is highly expressed in OSN axons when they grow to form initial connections with their targets in the olfactory bulb and is a critical regulator of Cas tyrosine phosphorylation in these
2D ECM
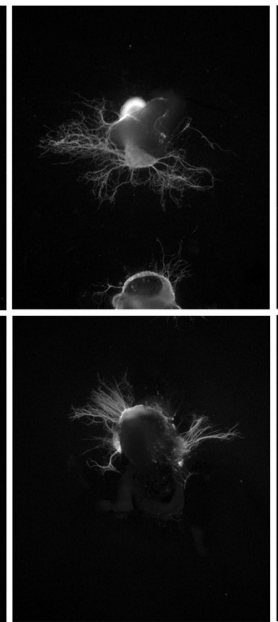

3D ECM
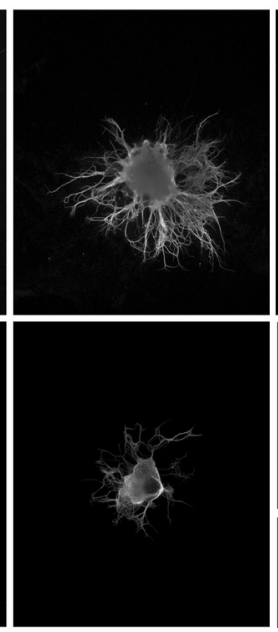
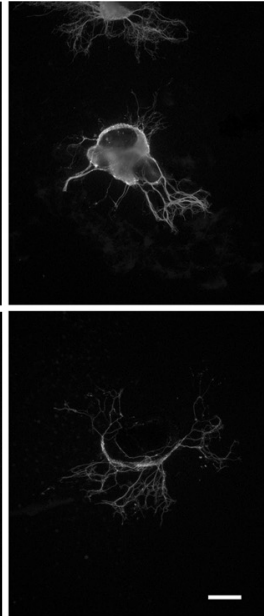

B

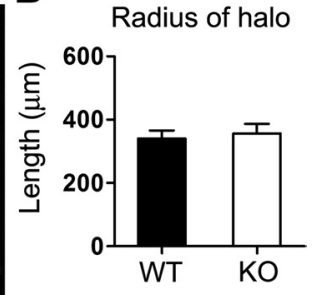

Maximal length

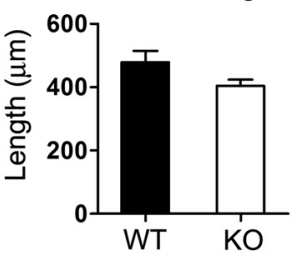

D
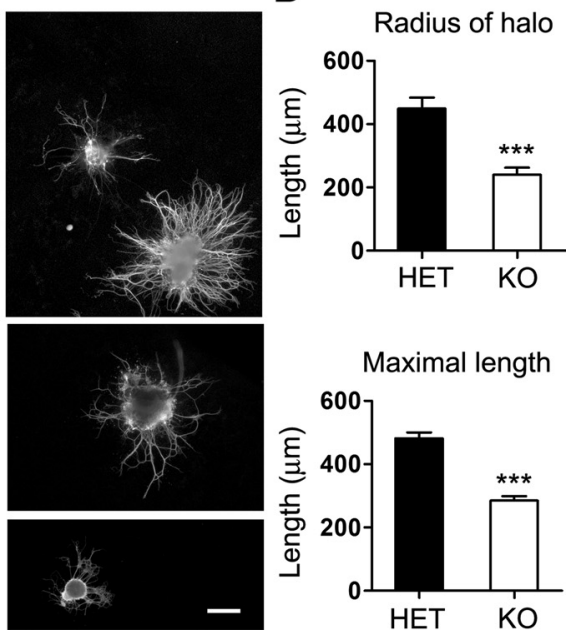

Figure 6. Shep1 knock-out olfactory axons grow less efficiently than control axons within a three-dimensional extracellular matrix. $A$, Explants from the E14.5 olfactory epithelium of control wild-type (WT) or Shep1 knock-out (K0) mice were grown on surfaces coated with GelTrex (2D ECM) for $5 \mathrm{~d}$. Scale bar, $250 \mu \mathrm{m}$. B, Quantification of the radius of the halo of processes growing round the explants and of the length of the longest neurites in each explant (see Materials and Methods). Measurements are $>0.05$ by Student's $t$ test. For maximal length: WT explants, $479 \pm 36 \mu \mathrm{m}, n=21 ; \mathrm{KO}$ explants, $404 \pm 31 \mu \mathrm{m}, n=13 ; p>$ GelTrex three-dimensional extracellular matrix (3D ECM) and allowed to grow for $5 \mathrm{~d}$. Scale bar, $250 \mu \mathrm{m}$. D 列 $49 \pm 35 \mu \mathrm{m}, n=20 ; \mathrm{K} 0$ explants, $240 \pm 23 \mu \mathrm{m}, n=24 ;{ }^{* * *} p<0.001$ by Student's test. For maximal length: WT explants, $482 \pm 18 \mu \mathrm{m}, n=20 ; \mathrm{K} 0$ explants, $285 \pm 14 \mu \mathrm{m}, n=24 ;{ }^{* * *} p>0.001$ by Student's $t$ test.

axons, we performed in vitro assays to determine whether Shep1 regulates OSN axon outgrowth. Explants from dissected E14.5 olfactory neuroepithelium were grown on surfaces coated with a thin layer of extracellular matrix proteins. Neuronal processes extended out similarly from both control and Shep1 knock-out explants, and, at $5 \mathrm{~d}$ in vitro, we did not detect differences in neurite length (Fig. 6A,B). These data suggest that Shep1 is not required for efficient OSN axon extension, consistent with the observation that in vivo OSN axons appear to grow normally in the nasal mesenchyme and to reach the basement membrane of the forebrain at approximately the appropriate time in the Shep 1 knock-out mice.

The explants were also embedded in a three-dimensional gel of extracellular matrix proteins to mimic the basement mem- 


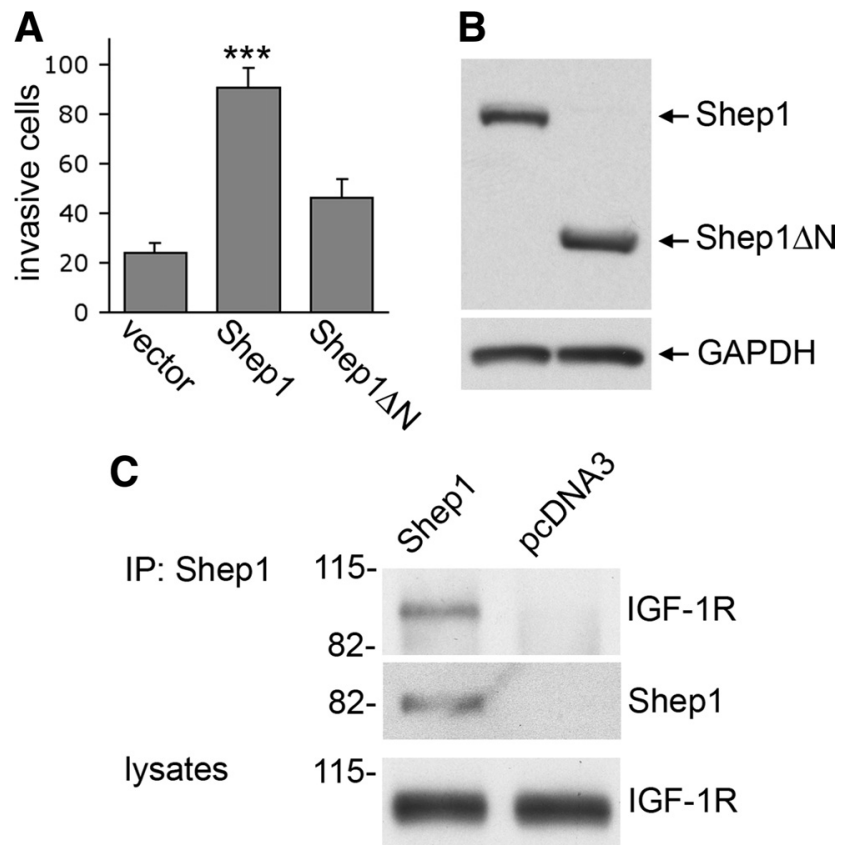

Figure 7. Shep1 promotes cell invasion through collagen. $\boldsymbol{A}$, HEK 293 cells transfected with wild-type Shep1, a truncated form of Shep1 lacking the N-terminal portion (SHEP1 $\Delta \mathrm{N}$ ), or control vector were plated in the upper chamber of Transwells and allowed to migrate through a layer of collagen I toward 50 nm IGF-1 in the lower chamber. Cells in the lower chamber were counted after $72 \mathrm{~h}$. The histogram shows averages from three experiments, each with two to four wells for each construct. ${ }^{* * *} p<0.001$ for the comparison with control-transfected cells by one-way ANOVA, followed by Bonferroni's multiple comparisons test. SHEP1 $\Delta \mathrm{N}$-transfected cells were significantly different from Shep1-transfected cells $(p<0.001)$ but not from control vector-transfected cells. $\boldsymbol{B}$, Immunoblots of transfected Shep 1 and Shep $1 \Delta \mathrm{N}$, showing similar expression of the two constructs. The blot was also probed for glyceraldehyde-3-phosphate dehydrogenase (GAPDH) to verify equal loading of the lanes. C, Shep1 coimmunoprecipitates with endogenous IGF-1 receptor. Immunoprecipitates (IP) with anti-Shep1 antibodies from cells transfected wild-type Shep1 or with empty vector as a control were probed for Shep1 or IGF-1 receptor. The levels of IGF-1 receptor in the lysates are also shown. The figure is representative of the results of three independent experiments.

brane surrounding the embryonic brain, which the OSN axons have to cross to reach the olfactory bulb. Neuronal processes grew out from the explants, penetrating into the matrix and forming a halo around the explants (Fig. 6C). Interestingly, the radius of the halo of processes surrounding the Shep1 knock-out explants at $5 \mathrm{~d}$ in vitro was significantly reduced in size compared with that in control explants (Fig. 6C,D). These data support the notion that Shep1 is needed for efficient axon growth through threedimensionally organized extracellular matrix proteins.

To further examine the role of Shep 1 in promoting the ability of cells to penetrate three-dimensional extracellular matrices, we transfected HEK 293 cells with cDNAs encoding either wild-type Shep1 or a $55 \mathrm{kDa}$ truncated form (Shep $1 \Delta \mathrm{N}$ ) similar to that expressed in Shep1 knock-out mice (Roselli et al., 2010). We then used transwell assays to examine the ability of the cells to cross a layer of collagen I, which is a component of the embryonic pial basement membrane at E13.5 (supplemental Fig. 8, available at www.jneurosci.org as supplemental material). As a chemoattractant, we used IGF-1, which has been shown to act as a chemoattractant for OSN axon growth cones (Scolnick et al., 2008). As shown in Figure 7, $A$ and $B$, cells expressing wild-type Shep1 migrated through the collagen gel more efficiently than empty vector-transfected control cells. In contrast, cells expressing the Shep $1 \Delta \mathrm{N}$ fragment exhibited similar invasiveness as the control cells, which do not express detectable levels of Shep1. Interest- ingly, we found that transfected Shep 1 associates with endogenous IGF-1 receptor in HEK 293 cells grown in the presence of IGF-1 (Fig. 7C). These data show that Shep1 expression facilitates cell penetration through three-dimensional extracellular matrices.

\section{Defects in Shep1 knock-out mice that survive to adulthood}

The hypoplasia of the olfactory bulb observed in newborn Shep1 knock-out mice may be a consequence of the lack of innervation (Gong and Shipley, 1995; Hébert et al., 2003; Laub et al., 2005; Hirata et al., 2006). Indeed we detected increased apoptosis in the P0.5 olfactory bulb (Fig. 8A,B). We also detected abnormally high numbers of apoptotic cells in the P0.5 olfactory epithelium lacking Shep1 (Fig. 8C,D). The increased apoptosis in the epithelium is likely attributable to the impaired ability of OSN axons to form synaptic connections with their targets and thus to a deficiency in target-dependent trophic support (Schwob et al., 1992; Watanabe et al., 2009). Indeed, it was not observed at E14.5 when trophic support does not play a role (supplemental Fig. 3C, available at www.jneurosci.org as supplemental material).

A small percentage of the Shep1 knock-out mice survives past P1 and reaches adulthood. In 14 surviving Shep1 knock-out mice, the olfactory bulb hypoplasia persisted into adulthood, although in 13 of the 14 mice one olfactory bulb was less severely affected than the other (Fig. 9), suggesting that the surviving mice may have a less severe phenotype. Although adult Shep1 knockout mice do not have major defects in overall brain architecture (supplemental Fig. 9, available at www.jneurosci.org as supplemental material), histological examination showed that the affected olfactory bulbs display severe lamination defects, characterized by loss of a complete nerve fiber layer, lack of the stereotypic circular arrangement of interneurons in the glomerular layer, and absence of a distinct mitral cell layer (Fig. 9) (supplemental Fig. 9, available at www.jneurosci.org as supplemental material).

GnRH neuron precursors are born in the nasal region and migrate during early development along the olfactory nerve to enter the brain on their way to their final destination in the hypothalamus (Hardelin and Dodé, 2008; Dodé and Hardelin, 2009). Here they secrete GnRH, which is necessary for sexual development. If the olfactory nerve along which the GnRH neuron precursors migrate is not properly connected, the precursors would be expected to remain outside the brain and therefore fail to integrate into hypothalamic neural circuits. Indeed, we observed a marked decrease in GnRH immunoreactivity in the preoptic region of the Shep1 knock-out hypothalamus at P0.5 (supplemental Fig. 10 A, available at www.jneurosci.org as supplemental material). Furthermore, we found that the testes of three among the eight surviving adult male Shep1 knock-out mice were greatly reduced in size, whereas the others were only slightly smaller or similar in size compared with wild-type (supplemental Fig. 10B, available at www.jneurosci.org as supplemental material). This variability might depend on the extent of residual OSN connectivity in different adult Shep1 mutant mice.

\section{Discussion}

Shep1 is a multidomain signaling protein that contains an $\mathrm{SH} 2$ domain, followed by a guanine nucleotide exchange factor-like domain (Dodelet et al., 1999). Shep1 also binds Cas, a key player in integrin signaling. To examine the role of Shep1 in neural development, we generated Shep 1 knock-out mice (Roselli et al., 2010). We found that in these mice the olfactory bulbs are reduced in size and have severe defects in afferent innervation. 
Although OSN axons appear to grow normally within the mesenchyme between the olfactory epithelium and the olfactory bulb up to the boundary with the telencephalon, they do not appear to cross the pial basement membrane. Defects are already apparent as early as at E13, soon after wild-type OSN axons have begun to penetrate into the olfactory bulb. We indeed detected high levels of Shep1 expression in wild-type OSN axons at E13-E14, which is subsequently downregulated by E16. Shep1 immunoreactivity overlaps with that of neuronal markers (such as GAP43, olfactory marker protein, and $\beta$ III-tubulin) but not glial markers (such as p75NTR and S100 $\beta$ ). Furthermore, both Shep 1 and Cas proteins are concentrated in the OSN axons compared with the cell bodies.

Interestingly, Cas substrate domain tyrosine phosphorylation is greatly reduced in developing OSN axons of Shep1 knockout mice at E12.5 and E14.5. Both Shep1 and the related family member BCAR3/ AND-34 have been shown to promote Src-dependent phosphorylation of the scaffolding protein Cas, which allows Cas to recruit binding partners that promote actin polymerization, cell adhesion, and cell migration/invasion (Sakakibara et al., 2002; Riggins et al., 2003; Dail et al., 2004; Geiger, 2006; Regelmann et al., 2006; Schrecengost et al., 2007; Parekh and Weaver, 2009; Schuh et al., 2010; Roselli et al., 2010; Tikhmyanova et al., 2010). Several studies have also implicated Cas function in neurite outgrowth and axon guidance (Yang et al., 2002; J. Huang et al., 2006; Liu et al., 2007). Consistent with a role for Shep 1 and Cas in OSN axons, we found that in explants cultured from olfactory epithelium Shep 1 is needed for efficient axon penetration into a three-dimensional extracellular matrix environment. Forced expression of Shep1 also enhanced HEK 293 cell invasion through a collagen gel. These findings suggest that Shep 1 in concert with Cas promotes OSN axon invasiveness across the pial basement membrane.

Despite the substantial evidence supporting a role of Shep1 in OSN axons, some Shep1 expression is also detectable in the primordial olfactory bulb during the early establishment of OSN connections. Therefore, we cannot exclude that Shep1 function in the olfactory bulb, or even in the basal lamina, might play a role in OSN connectivity. It is also conceivable that a brief initial innervation of the olfactory bulb may occur before E13 but fail to be stabilized. Additional investigations at earlier developmental stages and conditional Shep1 inactivation in developing OSN neurons versus the primordial olfactory bulb will be necessary to conclusively establish the importance of Shep1 in OSN axons.

The molecules that function upstream of Shep1 to regulate OSN connectivity remain unknown. Shep1 could act downstream of cell surface receptors whose decreased function has been shown to also impair the afferent innervation of the olfactory bulb. For example, in FGF8 hypomorphic mice, OSN axons grow in the nasal region but fail to extend into the forebrain, presumably because of impaired FGF receptor activation (Chung et al., 2008). The prokineticin receptor-2 knock-out mice also have defects in the olfactory system that are similar to those in Shep 1 knock-out mice, including OSN axons that appear to grow normally within the nasal mesenchyme but remain outside the forebrain and hypoplastic olfactory bulbs with defective lamination (Matsumoto et al., 2006). We also found that Shep1 can associate with the activated IGF-1 receptor and promote invasiveness in response to IGF-1. Although IGF-1 receptor knockout mice do not lack olfactory bulb afferent innervation, IGF-1 receptor activation mediates chemoattraction of OSN growth cones and is required for OSN axon targeting to the lateral olfactory bulb (Scolnick et al., 2008). It will therefore be interesting to investigate whether Shep1 is also involved in other aspects of olfactory system development, such as axon guidance and fasciculation.

A number of transcriptional regulators have been shown to regulate olfactory bulb innervation by OSN axons and development, including the homeodomain transcription factors Dlx5 (Levi et al., 2003; Merlo et al., 2007) and Emx2 (Yoshida et al., 1997), the zinc finger transcription factor Klf7 (Laub et al., 2005), and the zinc-finger transcriptional repressor Fezf1 (Hirata et al., 2006; Watanabe et al., 2009). Similar to Shep1 knock-out mice, the basement membrane surrounding the olfactory bulb lacks fenestrations in the Dlx5 knock-out mice (Merlo et al., 2007). In addition, Fezf1-deficient OSN axons fail to penetrate the basal lamina surrounding the olfactory bulb, and loss of Fezf1 also impairs axonal growth from olfactory epithelium explants embedded in Matrigel (Watanabe et al., 2009). Thus, Shep1 might be one of the functional targets of these transcriptional regulators.

The Shep1 knock-out mice express, in at least some tissues, a truncated form of Shep1 that lacks the N-terminal portion, in- 


\section{A Adult}
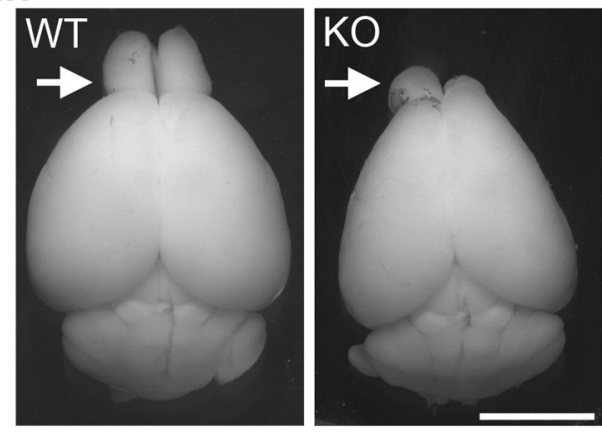

B
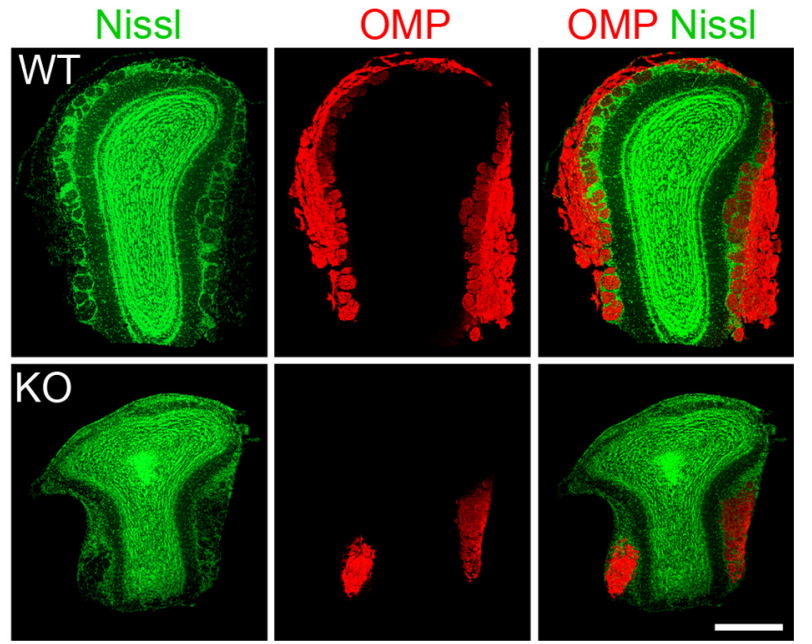

Figure 9. Hypoplastic and asymmetric olfactory bulbs with lamination defects in adult Shep 1 knock-out mice. $\boldsymbol{A}$, Adult brains illustrating an asymmetrical olfactory bulb malformation in the Shep1 knock-out. Arrows point to the olfactory bulbs. Scale bar, $5 \mathrm{~mm}$. B, Coronal sections of wild-type (WT) and Shep1 knock-out (KO) olfactory bulbs double labeled with Nissl green and anti-olfactory marker protein (OMP) antibody. Sections from the more affected olfactory bulb of the knock-out are shown. Scale bar, $500 \mu \mathrm{m}$.

cluding the SH2 domain (Roselli et al., 2010). This truncated form of Shep1, if it is expressed in the developing olfactory system, does not appear to interfere with the function of wild-type Shep1 in a dominant-negative manner because heterozygous mice do not display obvious defects in OSN axon connectivity. Furthermore, a Shep1 fragment similar to that expressed in the knock-out mice does not promote cell invasiveness when ectopically expressed in HEK 293 cells, suggesting that the truncated Shep1 expressed in the mutant mice is functionally deficient. Consistent with this, a truncated form of BCAR3/AND-34 without the $\mathrm{N}$ terminus and the $\mathrm{SH} 2$ domain has also been shown recently to have impaired function (Makkinje et al., 2009).

Although the Shep1 knock-out mice die perinatally, we have not detected major anatomical defects in newborn pups except for small olfactory bulbs. Insufficient feeding attributable to a defective sense of smell might explain the lethality observed in the C57BL/6 background (Contos et al., 2000; Matsumoto et al., 2006). Indeed, we have observed that many of the Shep1 knockout mice have little or no milk in their stomachs (Roselli et al., 2010). Furthermore, most of the surviving mice exhibit asymmetric abnormalities with one less affected olfactory bulb and may thus have retained some olfactory ability.

Olfactory bulb defects have not been reported for BCAR3/ AND34 knock-out mice (Near et al., 2009), and we did not detect BCAR3/AND34 mRNA in E15 olfactory neurons (data not shown). Consistent with a distinctive role of Shep1 in developing OSNs, we observed a dramatic reduction in Cas tyrosine phosphorylation in OSN axons of Shep1 knock-out mice. However, Shep1 and BCAR3/AND34 might have redundant functions in cells in which they are both expressed (Sakakibara and Hattori, 2000; Vervoort et al., 2007; Near et al., 2009). In agreement with this hypothesis, the BCAR3/AND34 knock-out mice also do not exhibit major abnormalities, except in the eye (Near et al., 2009). Because the third member of the family, NSP1, does not appear to be expressed in human neural tissue (Vervoort et al., 2007), Shep1 may also have a distinctive function in the human olfactory system.

The olfactory bulb hypoplasia, defects in GnRH neuron development, and small testes in the Shep 1 knock-out mice resemble the abnormalities observed in Kallmann syndrome patients. Kallmann syndrome is a developmental disease characterized by an impaired ability to smell often accompanied by hypoplasia of the olfactory bulb and by hypogonadism caused by defective GnRH neuron migration and/or differentiation (Hardelin and Dodé, 2008; Dodé and Hardelin, 2009). Although this syndrome was first described $>60$ years ago, only $\sim 30 \%$ of the genes whose mutations are responsible for the hereditary form of the disease have been identified, including mutations in the extracellular protein anosmin-1, FGF receptor 1 and its ligand FGF8, and prokineticin-2 and the prokineticin-2 receptor (Hardelin and Dodé, 2008; Dodé and Hardelin, 2009). Because our data suggest that Shep1 is a regulator of OSN connectivity, it will be interesting to determine whether mutations in the human SHEP1 gene may be involved in the etiology of Kallmann syndrome.

Note added in proof. An independently generated Shep1 knock-out mouse line has recently been reported that does not show perinatal lethality in a mixed 129/SvEvBrd and C57BL/6J genetic background (A1-Shami et al., 2010), suggesting that there are strain-specific differences that can modify the phenotype associated with Shep1 gene inactivation.

\section{References}

A1-Shami A, Wilkins C, Crisostomo J, Seshasayee D, Martin F, Xu N, Suwanichkul A, Anderson SJ, Oravecz T (2010) The adaptor protein Sh2d3c is critical for marginal zone B cell development and function. J Immunol 185:327-334.

Balmer CW, LaMantia AS (2004) Loss of Gli3 and Shh function disrupts olfactory axon trajectories. J Comp Neurol 472:292-307.

Cho JH, Prince JE, Cloutier JF (2009) Axon guidance events in the wiring of the mammalian olfactory system. Mol Neurobiol 39:1-9.

Chung WC, Moyle SS, Tsai PS (2008) Fibroblast growth factor 8 signaling through fibroblast growth factor receptor 1 is required for the emergence of gonadotropin-releasing hormone neurons. Endocrinology 149: 4997-5003.

Contos JJ, Fukushima N, Weiner JA, Kaushal D, Chun J (2000) Requirement for the lpA1 lysophosphatidic acid receptor gene in normal suckling behavior. Proc Natl Acad Sci U S A 97:13384-13389.

Dail M, Kalo MS, Seddon JA, Côté JF, Vuori K, Pasquale EB (2004) SHEP1 function in cell migration is impaired by a single amino acid mutation that disrupts association with the scaffolding protein cas but not with Ras GTPases. J Biol Chem 279:41892-41902.

Dodé C, Hardelin JP (2009) Kallmann syndrome. Eur J Hum Genet 17:139-146.

Dodelet VC, Pazzagli C, Zisch AH, Hauser CA, Pasquale EB (1999) A novel signaling intermediate, SHEP1, directly couples Eph receptors to R-Ras and Rap1A. J Biol Chem 274:31941-31946.

Geiger B (2006) A role for p130Cas in mechanotransduction. Cell 127:879-881.

Gong Q, Shipley MT (1995) Evidence that pioneer olfactory axons regulate telencephalon cell cycle kinetics to induce the formation of the olfactory bulb. Neuron 14:91-101. 
Hardelin JP, Dodé C (2008) The complex genetics of Kallmann syndrome: KAL1, FGFR1, FGF8, PROKR2, PROK2, et al. Sex Dev 2:181-193.

Hébert JM, Lin M, Partanen J, Rossant J, McConnell SK (2003) FGF signaling through FGFR1 is required for olfactory bulb morphogenesis. Development 130:1101-1111.

Hirata T, Nakazawa M, Yoshihara S, Miyachi H, Kitamura K, Yoshihara Y, Hibi M (2006) Zinc-finger gene Fez in the olfactory sensory neurons regulates development of the olfactory bulb non-cell-autonomously. Development 133:1433-1443.

Huang J, Sakai R, Furuichi T (2006) The docking protein Cas links tyrosine phosphorylation signaling to elongation of cerebellar granule cell axons. Mol Biol Cell 17:3187-3196.

Huang Z, Yazdani U, Thompson-Peer KL, Kolodkin AL, Terman JR (2007) Crk-associated substrate (Cas) signaling protein functions with integrins to specify axon guidance during development. Development 134:23372347.

Key B (1998) Molecular development of the olfactory nerve pathway. Ann N Y Acad Sci 855:76-82.

Laub F, Lei L, Sumiyoshi H, Kajimura D, Dragomir C, Smaldone S, Puche AC, Petros TJ, Mason C, Parada LF, Ramirez F (2005) Transcription factor KLF7 is important for neuronal morphogenesis in selected regions of the nervous system. Mol Cell Biol 25:5699-5711.

Levi G, Puche AC, Mantero S, Barbieri O, Trombino S, Paleari L, Egeo A, Merlo GR (2003) The Dlx5 homeodomain gene is essential for olfactory development and connectivity in the mouse. Mol Cell Neurosci 22: 530-543.

Liu G, Li W, Gao X, Li X, Jürgensen C, Park HT, Shin NY, Yu J, He ML, Hanks SK, Wu JY, Guan KL, Rao Y (2007) p130CAS is required for netrin signaling and commissural axon guidance. J Neurosci 27:957-968.

Long JE, Garel S, Depew MJ, Tobet S, Rubenstein JL (2003) DLX5 regulates development of peripheral and central components of the olfactory system. J Neurosci 23:568-578.

Lu Y, Brush J, Stewart TA (1999) NSP1 defines a novel family of adaptor proteins linking integrin and tyrosine kinase receptors to the c-Jun $\mathrm{N}$-terminal kinase/stress-activated protein kinase signaling pathway. J Biol Chem 274:10047-10052.

Makkinje A, Near RI, Infusini G, Vanden Borre P, Bloom A, Cai D, Costello CE, Lerner A (2009) AND-34/BCAR3 regulates adhesion-dependent p130Cas serine phosphorylation and breast cancer cell growth pattern. Cell Signal 21:1423-1435.

Matsumoto S, Yamazaki C, Masumoto KH, Nagano M, Naito M, Soga T, Hiyama H, Matsumoto M, Takasaki J, Kamohara M, Matsuo A, Ishii H, Kobori M, Katoh M, Matsushime H, Furuichi K, Shigeyoshi Y (2006) Abnormal development of the olfactory bulb and reproductive system in mice lacking prokineticin receptor PKR2. Proc Natl Acad Sci U S A 103:4140-4145.

Merlo GR, Mantero S, Zaghetto AA, Peretto P, Paina S, Gozzo M (2007) The role of Dlx homeogenes in early development of the olfactory pathway. J Mol Histol 38:347-358.

Mombaerts P (2006) Axonal wiring in the mouse olfactory system. Annu Rev Cell Dev Biol 22:713-737.

Near RI, Smith RS, Toselli PA, Freddo TF, Bloom AB, Vanden Borre P, Seldin DC, Lerner A (2009) Loss of AND-34/BCAR3 expression in mice results in rupture of the adult lens. Mol Vis 15:685-699.

Nedelec S, Dubacq C, Trembleau A (2005) Morphological and molecular features of the mammalian olfactory sensory neuron axons: What makes these axons so special? J Neurocytol 34:49-64.

Parekh A, Weaver AM (2009) Regulation of cancer invasiveness by the physical extracellular matrix environment. Cell Adh Migr 3:288-292.

Pitteloud N, Zhang C, Pignatelli D, Li JD, Raivio T, Cole LW, Plummer L, Jacobson-Dickman EE, Mellon PL, Zhou QY, Crowley WF Jr (2007) Loss-of-function mutation in the prokineticin 2 gene causes Kallmann syndrome and normosmic idiopathic hypogonadotropic hypogonadism. Proc Natl Acad Sci U S A 104:17447-17452.

Regelmann AG, Danzl NM, Wanjalla C, Alexandropoulos K (2006) The hematopoietic isoform of Cas-Hef1-associated signal transducer regulates chemokine-induced inside-out signaling and T cell trafficking. Immunity 25:907-918.

Riggins RB, Quilliam LA, Bouton AH (2003) Synergistic promotion of c-Src activation and cell migration by Cas and AND-34/BCAR3. J Biol Chem 278:28264-28273.

Rogers KE, Dasgupta P, Gubler U, Grillo M, Khew-Goodall YS, Margolis FL (1987) Molecular cloning and sequencing of a cDNA for olfactory marker protein. Proc Natl Acad Sci U S A 84:1704-1708.

Roselli S, Wallez Y, Wang L, Vervoort V, Pasquale EB (2010) The SH2 domain protein Shep1 regulates the in vivo signaling function of the scaffolding protein Cas. Cell Signal 22:1745-1752.

Sakakibara A, Hattori S (2000) Chat, a Cas/HEF1-associated adaptor protein that integrates multiple signaling pathways. J Biol Chem 275: 6404-6410.

Sakakibara A, Ohba Y, Kurokawa K, Matsuda M, Hattori S (2002) Novel function of Chat in controlling cell adhesion via Cas-Crk-C3G-pathwaymediated Rap1 activation. J Cell Sci 115:4915-4924.

Schrecengost RS, Riggins RB, Thomas KS, Guerrero MS, Bouton AH (2007) Breast cancer antiestrogen resistance- 3 expression regulates breast cancer cell migration through promotion of p130Cas membrane localization and membrane ruffling. Cancer Res 67:6174-6182.

Schuh NR, Guerrero MS, Schrecengost RS, Bouton AH (2010) BCAR3 regulates Src/p130 Cas association, Src kinase activity, and breast cancer adhesion signaling. J Biol Chem 285:2309-2317.

Schwob JE, Szumowski KE, Stasky AA (1992) Olfactory sensory neurons are trophically dependent on the olfactory bulb for their prolonged survival. J Neurosci 12:3896-3919.

Scolnick JA, Cui K, Duggan CD, Xuan S, Yuan XB, Efstratiadis A, Ngai J (2008) Role of IGF signaling in olfactory sensory map formation and axon guidance. Neuron 57:847-857.

St John JA, Clarris HJ, Key B (2002) Multiple axon guidance cues establish the olfactory topographic map: how do these cues interact? Int J Dev Biol 46:639-647.

Tikhmyanova N, Little JL, Golemis EA (2010) CAS proteins in normal and pathological cell growth control. Cell Mol Life Sci 67:1025-1048.

Tiveron MC, Hirsch MR, Brunet JF (1996) The expression pattern of the transcription factor Phox2 delineates synaptic pathways of the autonomic nervous system. J Neurosci 16:7649-7660.

Treloar HB, Nurcombe V, Key B (1996) Expression of extracellular matrix molecules in the embryonic rat olfactory pathway. J Neurobiol 31:41-55.

Vervoort VS, Roselli S, Oshima RG, Pasquale EB (2007) Splice variants and expression patterns of SHEP1, BCAR3 and NSP1, a gene family involved in integrin and receptor tyrosine kinase signaling. Gene 391:161-170.

Watanabe Y, Inoue K, Okuyama-Yamamoto A, Nakai N, Nakatani J, Nibu K, Sato N, Iiboshi Y, Yusa K, Kondoh G, Takeda J, Terashima T, Takumi T (2009) Fezf1 is required for penetration of the basal lamina by olfactory axons to promote olfactory development. J Comp Neurol 515:565-584.

Yang LT, Alexandropoulos K, Sap J (2002) c-SRC mediates neurite outgrowth through recruitment of Crk to the scaffolding protein Sin/Efs without altering the kinetics of ERK activation. J Biol Chem 277: 17406-17414.

Yoshida M, Suda Y, Matsuo I, Miyamoto N, Takeda N, Kuratani S, Aizawa S (1997) Emx1 and Emx2 functions in development of dorsal telencephalon. Development 124:101-111.

Yoshihara S, Omichi K, Yanazawa M, Kitamura K, Yoshihara Y (2005) Arx homeobox gene is essential for development of mouse olfactory system. Development 132:751-762.

Zaghetto AA, Paina S, Mantero S, Platonova N, Peretto P, Bovetti S, Puche A, Piccolo S, Merlo GR (2007) Activation of the Wnt-beta catenin pathway in a cell population on the surface of the forebrain is essential for the establishment of olfactory axon connections. J Neurosci 27:9757-9768.

Zimmer C, Tiveron MC, Bodmer R, Cremer H (2004) Dynamics of Cux2 expression suggests that an early pool of SVZ precursors is fated to become upper cortical layer neurons. Cereb Cortex 14:1408-1420. 